\title{
Yenilikçi finansman aracı olarak ekosistem hizmetleri için ödemeler: Firsat mı, tehdit mi?
}

Payments for ecosystem services as innovative financial instruments: An opportunity or a threat?

Güven KAYA ${ }^{1}$

${ }^{1}$ İç Anadolu Ormancılık Araştırma Enstitüsü Müdürülüğ̈̈, ANKARA

Sorumlu yazar (Corresponding author) Güven KAYA

guvenkaya@ogm.gov.tr

Geliş tarihi (Received)

24.11.2018

Kabul Tarihi (Accepted)

28.02.2019

Atıf (To cite this article): KAYA, G . (2019). Yenilikçi finansman aracı olarak ekosistem hizmetleri için ödemeler: Fırsat mı, tehdit mi?. Ormancılık Araştırma Dergisi, 6 (2), 96-107.

DOI: https://doi.org/10.17568/ogmoad.487229

\section{$\ddot{O} z$}

Orman kaynaklarının topluma sağladığı biyolojik çeşitliliği barındırma, estetik hizmetler, su ve toprak koruma, yaban hayatını barındırma gibi ekosistem hizmetlerinin üretimi için geleneksel anlamda pazar teşviki bulunmamaktadır. Son on yılda dünyada ekosistemlerin yönetiminde en popüler kavramlardan biri, ekosistem hizmetlerinin devamlılığını güvence altına almak için yenilikçi finansman araçlarını içeren, İngilizce kısaltması PES (payment for ecosystem services) olarak bilinen ekosistem hizmetleri için ödemelerdir. Ekosistem hizmetleri için ödeme programlarının habitat kullanma haklar1, koruma irtifakları ve imtiyazları, korunan alanları kiralama, ticari karbon, biyolojik çeşitlilik, havza koruma kredileri gibi çeşitli türleri bulunmaktadır. Bazıları ekosistem hizmetleri için ödeme programlarını orman ekosistemlerinin korunması için kurtarıcı olarak görürken karşıt görüştekilere göre ise ekosistem hizmetleri için ödeme programları kamu mallarının ticarileştirilerek tüketilmesi için bir araç olarak yeni pazarlar yaratma yollarından biridir. Bu makalede dünya ve Türkiye ölçeğinde ekosistem hizmetleri için ödeme programlar1nın orman ekosistemlerinin sürdürülebilir yönetimi açısından fırsat ve tehdit oluşturduğu koşullar irdelenmiş, kullanım olanakları değerlendirilmiştir.

Anahtar Kelimeler: Ekosistem hizmetleri için ödemeler, orman ekosistem hizmetleri, kamu malları, ticarileştirme, finansman

\begin{abstract}
There is no traditional market incentive for the production of forest ecosystem services such as biodiversity conservation, aesthetic services, water and soil conservation, wildlife preservation, etc. One of the most popular concepts in the ecosystem management over the last decade has been payments for ecosystem services (PES) which include innovative financing instruments to ensure the sustainability of ecosystem services. There are various types of PES such as habitat use rights, protection easements and concessions, leases for protected areas, commercial carbon, biodiversity, watershed protection credits. Some believe that PES programs can support conservation of forest ecosystems as a savior while others, on the contrary, think that PES programs are the means to create new markets for commercialization and exploitation of public goods. In this paper, opportunities and threats to sustainable management of forest ecosystems that have been created by PES programs were examined. Finally, the possibilities of PES programs in Turkey were evaluated.
\end{abstract}

Keywords: Payments for ecosystem services, forest ecosystem services, public goods, commercialization, financing 


\section{Giriş}

Orman ekosistemleri odun, odun diş1 orman ürünleri, ot, rekreasyon hizmetleri gibi doğrudan kullanım değerine sahip ürün ve hizmetlerin yanı sıra, toprak koruma, sel kontrolü, karbon tutma gibi işlevleriyle dolaylı kullanım değerine sahip hizmetler de üretmektedir. Toplam ekonomik değer çerçevesinde bu değerler, kullanım yahut aktif kullanım değerleri olarak nitelendirilmektedir. Diğer yandan, orman ekosistemlerinin bir parçası olan, ancak gelecekte kendisinin de kullanabileceği, ilaç keşfinde kullanılabilecek bir bitki türünün korunmasının insanlar için değeri vardır (gelecek değeri). İnsanlar, aynı zamanda bazı orman ekosistemlerinin faydalarından çocuk ve torunlarının da yararlanmasını ister (miras değeri). Yahut kendisi veya başkası hiç faydalanmayacak olsa dahi, insan dışı varlıklar için ormanlar korunduğundan orman ekosistemlerine değer (varlık değeri) atfedenler vardır. Gelecek, miras ve varlık değerleri pasif kullanım değerleri grubunda yer alır.

Başta dolaylı kullanım ve pasif kullanım değerlerine sahip hizmetler olmak üzere, bu ürün ve hizmetlerin büyük bölümünün geleneksel anlamda belirgin pazar fiyatları yoktur veya rekreasyon hizmetlerinde olduğu gibi idari olarak belirlenmiş kullanım bedellerinden söz edilmektedir. $\mathrm{Bu}$ tür ürün ve hizmetlere pazarı olmayan ürün ve hizmetler denilmektedir (Kaya, 2002).

Orman ekosistemlerinin sunduğu pazarı olmayan ürün ve hizmetlerin pazar fiyatlarının olmaması, faydalarının dışsal nitelikte olmasına, aktif kullanım değerlerine sahip olmalarına rağmen orman sahiplerinin bu tür ürün ve hizmetlerden gelir elde edememesine yol açmaktadır. Bu ürün ve hizmetlerin faydalarının bölünememesi ve dışlanamama özelliklerini yüksek derecede taşımaları kamu malı olarak nitelendirilmelerine yol açmaktadır. Örneğin, ormanların sel kontrolü işleviyle havzanın aşağısındaki arazi sahiplerine sağladığı faydalardan herhangi bir tarım arazisi sahibi dışlanamamaktadır ve orman sahibinin bu hizmeti sağlarken katlandığı maliyetler, tarım arazilerinin sahiplerinin muhasebe kayıtlarına yansımamaktadır. Hem dışsal faydalar yayan hem de kamu malı niteliklerine sahip olan sel kontrolü hizmetini üretmek için orman sahibinin tam rekabet piyasası açısından teşviki bulunmamaktadır ve bu durum piyasa başarısızlığı olarak adlandırılır.

Tam rekabet piyasası açısından, küresel düzeye yayılabilen pasif kullanım değerlerini de yansitabilecek pazar ortamı bulunmamaktadır. Örneğin bağışlar, biyolojik çeşitliliği korumak için her varlık değeri bulunduranın ödeme eğilimlerini yansitabilecek ortamı sağlayamamaktadır. Bu durumun temel nedenleri pasif kullanım değerlerine sahip ekosistem hizmetlerinin bedavacilık problemi yaratan kamu malı ve dışsallık nitelikleridir.

Pazar teşvikinin olmadığı koşullarda orman kaynaklarından biyolojik çeşitliliği barındırma, estetik hizmetler, su ve toprak koruma, yaban hayatını barındırma gibi ekosistem hizmetleri üretimi ancak kamu finansmanı veya bağışlarla mümkün olabilmektedir. Özellikle özel orman sahipleri, ormanlarının yönetiminde bu tür işlevleri öncelememektedir.

Pazar teşvikinin gerekliliği, son on yılda tüm dünyada orman kaynakları başta olmak üzere tüm ekosistemlerin yönetiminde en popüler kavramlardan birinin doğmasına yol açmıştır. Bu kavram, ekosistem hizmetlerinin devamlılığını güvence altına almak için yenilikçi finansman araçlarını içeren, İngilizce kısaltması PES (payment for ecosystem services) olan ekosistem hizmetleri için ödemelerdir veya ekosistem hizmetleri için tediyedir.

Ekosistem hizmetleri için ödeme programlarının habitat kullanma hakları, koruma irtifakları ve imtiyazları, korunan alanları kiralama, koruma için yönetim sözleşmeleri, ticari karbon, biyolojik çeşitlilik, havza koruma kredileri gibi çeşitli türleri bulunmaktadır. Günümüzde dünyada 550'yi aşan aktif ekosistem hizmetleri için ödeme programının yıllık işlem hacminin yaklaşık 36-40 milyar \$ olduğu ve bu miktarın büyük bölümünün su, karbon ve biyolojik çeşitlilikle ilgili ekosistem hizmetleri için ödeme programı olduğu, orman ekosistemlerinin bu programların önemli bölümünü kapsadığı tahmin edilmektedir (Salzman ve ark., 2018). Bununla birlikte, Orman İşbirliği Ortaklığı bünyesinde kurulan Finans Danışma Grubu raporuna (Anonim, 2012) göre, küresel düzeyde sürdürülebilir orman yönetimi için gereken ilave fon 70-160 milyar \$ arasindadir.

Ekosistem hizmetleri için ödeme programları başta Latin Amerika ve Çin olmak üzere ABD, Avrupa ve Afrika ülkelerinde de hızla yayılırken konuyla ilgili tartışmalar da artmaktadır. Bir görüşe göre, ekosistem hizmetleri için ödeme programları orman ekosistemlerinin korunması için aranan finansman kaynağı ve kurtarıcı olabilir. Karşıt görüşe göre ise ekosistem hizmetleri için ödeme programları, kamu mallarının ticarileştirilerek tüketilmesi ve sömürülmesi için bir araç olarak yeni pazarlar yaratma yollarından biridir. Diğer bir deyişle, ekosistem hizmetleri için ödeme programları sürdürülebilir orman kaynakları yönetimi için firsat veya tehdit oluşturabilir. $\mathrm{Bu}$ fırsat ve tehditler, ekosistem hizmetleri için ödeme 
programlarının çerçevesi, ülkenin sosyal ve ekonomik koşulları, ülke ormancılığının yapısı, orman ekosistemlerinin özellikleri, sunulan ekosistem hizmetlerinin türüne bağlı olarak değişebilir. $\mathrm{Bu}$ makalede ekosistem hizmetleri için ödemeler kavramının tanımları, türleri, program yapıları örneklerle açıklanarak dünya ve Türkiye ölçeğinde orman ekosistemlerinin sürdürülebilir yönetimi açısından firsat ve tehdit oluşturduğu koşullar irdelenmiş, kullanım olanakları değerlendirilmiştir.

\subsection{Tanımlar}

Ekosistem hizmetleri için ödemeler terimi, ilk kez 2000 yılında Kosta Rika için yeni politika çerçevesinin çizildiği Dünya Bankası Raporunda İspanyolca olarak (pagos per services ambientales) kullanılmıştır (Derissen ve Lohmann, 2013). Literatürde en çok bilinen ve atıf alan "ekosistem hizmetleri için ödemeler" tanımı 2005 yılında Sven Wunder tarafından yapılmıştır. Wunder'e (2005) göre, bir çevresel hizmet için ödeme, iyi tanımlanmış bir çevresel hizmetin (veya arazi kullanımının) sadece ve sadece arz güvencesi veren en az bir sağlayıcıdan en az bir alıcı tarafından satın alındığı gönüllü işlemdir.

Ekosistem hizmetleri için ödemelerle ilgili sekiz tanım daha bulunmaktadır (Wunder, 2015). Bu tanımlar arasında Wunder'in tanımına göre farklılık yaratan tanım Muradian ve ark. (2010) tarafindan yapılmıştır. Bu tanıma göre ekosistem hizmetleri için ödemeler, doğal kaynak yönetiminde bireysel ve/veya kolektif arazi kullanım kararlarını toplumsal ilgiye uyumlu hâle getirmek için teşvikler yaratmak amaciyla toplumsal aktörler arasında kaynakların transferidir.

Ekosistem hizmetleri için ödeme programlarının aktörleri, satıcılar, alıcılar ve aracılardır. Bu aktörler programların sınıflandırılması, tasarımı ve gerçekleştirilmesinde önemli role sahiptir.

Satıcılar, özel ve kamu mülkiyet hakkı sahibi ekosistem hizmeti sağlayıcılarıdır. Wunder'in (2005) tanımına dayanan literatür, özel şahıslar, şirketler, ulusal veya yerel hükümet dışı diğer arazi sahiplerinin (belediyeler, yerel topluluklar) ekosistem hizmeti satıcısı olabileceğini ifade etmektedir (Madsen ve ark., 2011).

Ekosistem hizmetleri için ödeme programlarında alıcılar ise, pasif kullanım değerlerini önemseyen kamu yararına çalışan alıcılar, topluma fayda sağlayan ekosistem hizmetlerini güvence altına almak isteyen kamu sektöründen farklı ölçeklerde alıc1lar, ekosistemlerin aktif kullanım değerlerini ve diğer özel faydalarını güvence altına almak için özel ilgisi olan özel şirketler, organizasyonlar ve topluluklar, ekolojik etkilerin takası için düzenlemelerle yükümlülüğü olan özel alıcılar, hem aktif hem de pasif kullanım değerlerini önemseyen ekolojik sertifikalı ürün alıcıları olarak sınıflandırılabilir (Scherr ve ark., 2006).

Ekosistem hizmetleri için ödeme programlarında ekosistem hizmetleri sağlayanlarla faydalananlar arasındaki işlemleri kolaylaştırmak, örneğin bağlantıları kurmak, program tasarlamak, uygulamayı denetlemek, finansman bulmak için aracılara ihtiyaç duyulmaktadır. Ulusal ve uluslararası düzeyde çalışan STK'lar, uluslararası kuruluşlar, kamu kurumları, yerel organizasyonlar, bankalar ve diğer finansal aracı şirketleri, profesyonel danışmanlık şirketleri, araştırmacılar, üniversiteler ve diğer teknik destek kurumları aracı olabilmektedir.

\subsection{Ekosistem hizmetleri için ödeme programlarına örnekler}

Dünyada ekosistem hizmetleri için ödeme programlarının sayısı ve yıllık işlem hacminin ekosistem hizmetleri kaynaklarına göre dağılımı şu şekildedir (Salzman ve ark., 2018):

- Su havzalarını koruma amacıyla ekosistem hizmetleri için ödeme programları 62 ülkede 24,7 milyar \$ değere ulaşmıştır. Günümüzde havza düzeyinde yürütülen 387 ekosistem hizmetleri için ödeme programının 153'ü kullanıcıların, 203’ü hükümetlerin finanse ettiği, 31'i ise uyum için finanse edilen programlardır.

- Biyolojik çeşitlilik ve habitat için 36 ülkede 120 aktif ekosistem hizmetleri için ödeme programı bulunmaktadır. Finansman kaynağı açısından bu ödemelerin 16'sı kullanıcılar tarafından finanse edilen, 104'ü ise uyum için yürütülen ekosistem hizmetleri için ödeme programıdır. Y1llık işlem hacminin 2,5 ila 8,4 milyar $\$$ arasinda olduğu tahmin edilmektedir.

- Ormanlar ve arazi kullanımı kaynaklı karbon pazarında halen 31'i hükümetler tarafından finanse edilen, 17'si uyum için olmak üzere 48 ekosistem hizmetleri için ödeme programı mevcuttur. $\mathrm{Bu}$ programların değeri 8 milyar \$'ın üzerindedir.

Tablo 1'de dünyada gerçekleştirilen ekosistem hizmetleri için ödeme programlarına bazı örnekler verilmiştir.

\section{Materyal ve Yöntem}

Araştırma konusunun odağında yer alan ekosistem hizmetleri, ekosistem hizmetleri için ödemeler ve 
ekosistem hizmetlerinin ekonomik değerinin belirlenmesi olgularına ilaveten konunun kavramsal temelini oluşturan iktisat teorilerine ilişkin literatürde yer alan teorik ve pratik araştırmalara dayanan makaleler, kitaplar, tezler ve raporlar araştırmanın materyalini oluşturmuştur. Literatür taraması yöntemi ile toplanan bilgiler, bilgi birikimi ile değerlendirilerek bu araştırma hazırlanmıştır.

\section{Bulgular}

\subsection{Kavramsal çelişkiler}

Ekosistem hizmetleri için ödemeler ile ilgili terminolojide kapsamı etkileyebilen üç çelişsili terim kullanımı veya tanımlama sorunu söz konusudur. Birincisi, İngilizce kısaltmaları aynı (PES) olan

Tablo 1. Ekosistem hizmetleri için ödeme programlarına örnekler* Table 1. Some examples of PES programs

\begin{tabular}{|c|c|c|c|c|}
\hline Ülke, Program & Satic1 & Alıc1 & Hizmet & Ödeme şekli/koşulu \\
\hline Fransa, Vittel & Orman sahipleri & $\begin{array}{l}\text { Nestle-Vittel mineral } \\
\text { su firmas1 }\end{array}$ & $\begin{array}{l}\text { Su kalitesi } \\
\text { sürekliliği }\end{array}$ & Doğrudan ödeme \\
\hline İsviçre, Henniez & $\begin{array}{l}\text { Tarım arazisi } \\
\text { sahipleri }\end{array}$ & $\begin{array}{l}\text { Henniez SA mineral } \\
\text { su firmas1 }\end{array}$ & $\begin{array}{l}\text { Su kalitesi } \\
\text { sürekliliği }\end{array}$ & $\begin{array}{l}\text { Tarım arazilerini satın } \\
\text { alma ve ağaçlandırma }\end{array}$ \\
\hline Almanya & $\begin{array}{l}\text { Kamu ve özel orman } \\
\text { sahiplerinden oluşan } \\
\text { İçme Suyu Ormanı } \\
\text { Birliği }\end{array}$ & BIONADE firmas1 & $\begin{array}{l}\text { Su kalitesi } \\
\text { sürekliliği }\end{array}$ & $\begin{array}{l}\text { Ormanların yapraklı } \\
\text { ormana dönüştürülmesi } \\
\text { giderlerinin karşılanması }\end{array}$ \\
\hline Avustralya & $\begin{array}{l}\text { Devlet Orman } \\
\text { İdaresi }\end{array}$ & $\begin{array}{l}\text { New South Wales'de } \\
\text { tarımsal sulama } \\
\text { ortaklığ } 1\end{array}$ & $\begin{array}{l}\text { Su tuzluluğunun } \\
\text { olumsuz etkilerini } \\
\text { azaltma }\end{array}$ & $\begin{array}{l}\text { Yukarı havzadaki ağaç- } \\
\text { landırma çalışmaları }\end{array}$ \\
\hline $\begin{array}{l}\text { ABD, New York } \\
\text { Catskills Su } \\
\text { Havzası Yönetim } \\
\text { Program1 }\end{array}$ & $\begin{array}{l}\text { Çiftçiler ve orman } \\
\text { sahipleri }\end{array}$ & New York halk1 & İçme suyu kalitesi & $\begin{array}{l}\text { İlave su ücreti ile } \\
\text { sürdürülebilir arazi } \\
\text { kullanımı ve yönetim } \\
\text { uygulamaları }\end{array}$ \\
\hline İsviçre & $\begin{array}{l}\text { Basel-Stadt Kan- } \\
\text { tonunda } 330 \text { özel } \\
\text { orman sahibi }\end{array}$ & $\begin{array}{l}\text { Belediyeler ve su tüke- } \\
\text { ticileri }\end{array}$ & $\begin{array}{l}\text { Su kalitesi ve mik- } \\
\text { tarının sürekliliği }\end{array}$ & $\begin{array}{l}\text { Su faturalarına ek öde- } \\
\text { meler karşıllğında or- } \\
\text { manlarda tür değişimleri } \\
\text { ve diğer uygulamalar }\end{array}$ \\
\hline $\begin{array}{l}\text { Finlandiya, MET- } \\
\text { SO Program1; } \\
\text { İsveç, KOMET } \\
\text { Programı }\end{array}$ & $\begin{array}{l}\text { Küçük orman } \\
\text { sahipleri }\end{array}$ & Hükümet & $\begin{array}{l}\text { Biyolojik çeşitliliği } \\
\text { koruma }\end{array}$ & $\begin{array}{l}\text { Koruma alanları kurma } \\
\text { karş1lı̆̆ında doğrudan } \\
\text { ödeme veya arazilerin } \\
\text { devlete satılması }\end{array}$ \\
\hline $\begin{array}{l}\text { Moldova, Toprak } \\
\text { Koruma Projesi }\end{array}$ & $\begin{array}{l}\text { Bozuk ve erozyona } \\
\text { uğramış tarım ara- } \\
\text { zisi sahibi Devlet ve } \\
\text { topluluklar }\end{array}$ & $\begin{array}{l}\text { Temiz kalkınma me- } \\
\text { kanizması çerçevesin- } \\
\text { de biyokarbon fonu ve } \\
\text { prototip karbon fonu }\end{array}$ & Karbon tutma & $\begin{array}{l}\text { Tarım arazilerinin ağaç- } \\
\text { landırılması ve ormana } \\
\text { çevrilmesi karş1lığında } \\
\text { karbon için ödeme }\end{array}$ \\
\hline Gürcistan & $\begin{array}{l}\text { Terk edilmiş arazi } \\
\text { sahipleri }\end{array}$ & Uluslararası fonlar & Karbon tutma & $\begin{array}{l}\text { Agri Georgia şirketi } \\
\text { aracılığıyla fındık plan- } \\
\text { tasyonları kurulması } \\
\text { karş1lığında karbon kre- } \\
\text { dileri ile ödeme }\end{array}$ \\
\hline $\begin{array}{l}\text { Çin, Yeşil Buğday } \\
\text { Projesi }\end{array}$ & $\begin{array}{l}\text { Orman arazilerine } \\
\text { sahip çiftçiler }\end{array}$ & Uluslararası fonlar & $\begin{array}{l}\text { Erozyon ve ne- } \\
\text { hirlerde sediman- } \\
\text { tasyonu önleme, } \\
\text { karbon tutma }\end{array}$ & $\begin{array}{l}\text { Arazilerindeki ormanları } \\
\text { korumaları karş1lığın- } \\
\text { da karbon kredileri ile } \\
\text { ödeme }\end{array}$ \\
\hline Güney Galler & $\begin{array}{l}\text { Arazi sahipleri, biyo- } \\
\text { lojik çeşitlilik koru- } \\
\text { ma girişimleri }\end{array}$ & $\begin{array}{l}\text { Biyolojik çeşitliliğe } \\
\text { zarar veren firmalar }\end{array}$ & $\begin{array}{l}\text { Biyolojik çeşitliliğ } i \\
\text { koruma }\end{array}$ & $\begin{array}{l}\text { Biyolojik çeşitlilik mah- } \\
\text { suplaşması ve bankacılığ1 } \\
\text { çerçevesinde koruma gi- } \\
\text { rişimlerinden kredi satın } \\
\text { alınması veya takası }\end{array}$ \\
\hline $\begin{array}{l}\text { Malezya, Malua } \\
\text { BioBank1 koruma } \\
\text { programı }\end{array}$ & Hükümet & $\begin{array}{l}\text { Uluslararası firmalar, } \\
\text { kuruluşlar, hayırse- } \\
\text { verler }\end{array}$ & $\begin{array}{l}\text { Orangutan varlığ } 1- \\
\text { nın korunması }\end{array}$ & $\begin{array}{l}\text { Yağmur ormanının res- } \\
\text { torasyonu için biyolojik } \\
\text { çeşitlilik koruma } \\
\text { sertifikalarının satılması }\end{array}$ \\
\hline
\end{tabular}

* Salzman ve ark. (2018), Anonim (2008), Stanton ve ark. (2010), Anonim (2011) ile Anonim (2014)'den uyarlanmıştır. 
ekosistem hizmetleri için ödemeler ve çevresel hizmetler için ödemeler terimlerinin hangisinin doğru olduğudur.

En çok atıf yapılan tanımda (Wunder, 2005) çevresel hizmetler terimi kullanılmasına rağmen, günümüzde ekosistem hizmetleri nitelemesi daha yaygındır. Bu tercih farklılığ 1 iki terimin tanımı ve kapsamından kaynaklanmaktadır. Bazıları (Anonim, 2018), çevresel hizmetleri ekosistem hizmetlerinin alt sınıfı olarak görürken tersini düşünenler de vardır (Muradian ve ark., 2010; Myers, 1996). FAO (Anonim, 2018), ekosistem hizmetlerini insanların ekosistemlerden elde ettiği tüm faydalar olarak tanımlayan Binyıl Ekosistem Değerlendirmesi (MEA) tanımını (Anonim, 2005) kullanmakta, çevresel hizmetleri ise kasıtsız dışsallıklar olarak nitelendirmektedir.

Burada temel sorun, ekosistem hizmetleri için MEA tanımının yaygın kabul görmesi, fakat çevresel hizmetler konusunda fikir birliğinin olmamasıdır. Bir görüşe göre (Derissen ve Lohmann, 2013), bu tartışmada kasıtlı veya kasıtsız üretildiğine bakılmaksızın, insan yapımı doğasına dayanarak ancak insan yapımı koruma etkinlikleri için ödemeler söz konusu olabilir; o nedenle çevresel hizmetler için ödemeler teriminin kullanılması gerekir. Aynı görüş, doğanın banka hesabı olmayacağını vurgulamaktadır. İnsan müdahalesi olmaksızın üretilen ekosistem hizmetleri için ödemelerin mantığının olmadığını savunan yukarıdaki yaklaşımda doğanın rolünü insanoğlu sahiplenmektedir (meta fetişizmi). Biyolojik çeşitliliği korumak için tasarlanan bir ekosistem hizmetleri için ödeme programı ile insan müdahalesi kalktığında ekosistem hizmeti sağlanmaya devam etmektedir. O nedenle hizmet sağlayıcısı yerine aktör betimlemesi daha isabetlidir.

Ekosistem hizmetleri için ödemelerin tanımıyla ilgili ikinci terminolojik sorun, ekosistem hizmetleri, değer belirleme ve ekosistem hizmetleri için ödemeler kavramları ve kısaltmalarının karıştırılabilmesidir. Ekosistem hizmetleri için ödemeler, ekosistem hizmetlerinin faydaları karşılığında yapılan ödemeleri ifade etmektedir. Ekonomik değer belirleme (valuation) ise bu faydaların insan refahında yarattığı değişimin ölçüsüdür ve ekosistemlerin yarattığ 1 aktif ve pasif kullanım değerlerini tahmin etmek için kendine özgü yöntembilime sahip, çevre ve orman ekonomisi çalışma alanıdır.

Üçüncüsü ise ekosistem hizmetleri için ödemelerin terim anlamı ile iki önemli tanımı (Wunder, 2005; Muradian ve ark., 2010) arasındaki farklılıktır. Wunder'in tanımının aksine, ekosistem hizmetleri için ödemelerin terim anlamı tüm ekosistem hizmetleri için kimin sağladığına ve nasıl sağlandığ1na bakılmaksızın her türlü ödemeleri kapsamaktadir. Muradian ve ark.'1nın (2010) tanımı ise terim anlamına yakındır.

Ekosistem hizmetleri için ödemelerin tanımlarında iki ucu temsil eden bu tanımlar arasındaki temel fark, dışsallıkların içselleştirilmesinde işletilebilecek tazminat mekanizmasına yönelik Coase ve Pigou'nun yaklaşımlarındaki ayrımdan kaynaklanmaktadır. Pigou, dışsallıkların içselleştirilmesi için vergiler, harçlar ve kullanım bedellerinin kullanılmasını önerirken Coase taraflar arasında özel sözleşmelerle tazminat sorununun çözülebileceğini savunmaktadır (Kaya, 2002). Wunder'in tanımının Coase'nin yaklaşımını, diğerinin ise Pigoucu yaklaşımı izlediği görülmektedir. Günümüzde orman sahipleri ile faydalanıcılar arasında sözleşmelere dayalı örnekler olduğu gibi, vergilerle çalıştırılan ekosistem hizmetleri için ödeme fonları olduğu, hatta mantar toplama için izin bedellerine dayalı ekosistem hizmetleri için ödeme programlarının tasarlandığ

Ekosistem hizmetleri için ödemelerin yenilikçi yönünün özellikle, kirleten öder değil, faydalanan öder ilkesine dayandığ 1 ifade edilmektedir (Wunder, 2005). Örneğin, yukarı havzadaki orman kaynaklarının hidrolojik işlevlerinin çıktıları için aşağ1 havzada faydalanan toplumun ödeme yapması özel orman sahiplerini teşvik edebilir. Buna karşın koruma bankacılığında, mahsup (offset) işlemlerinde gerek biyolojik çeşitlilik gerekse karbon için ekosistemlere verilen zarar karşılığında ödeme yapılması, ekosistem hizmetleri için ödeme programlarının sadece faydalanan öder değil, aynı zamanda uluslararası süreç ve sözleşmelerde geniş kabul görmüş kirleten öder ilkesinin de geçerli olduğunu göstermektedir.

\subsection{Ticarileştirme}

Wunder (2005) ve taraftarlarının düşüncesi, ekosistem hizmetleri için ödeme programları ile dişsallık yayan ekosistem hizmetinin faydayı sağlayanlara satılması, arazi sahiplerinin tazmin edilerek dışsallıkların içselleştirilmesidir. Pazarı olmayan mal olarak nitelenen ekosistem hizmetlerinin pazar ortamında satışa konu olabilmesine kamu malı nitelikleri engel teşkil etmektedir.

Tüketimden (kullanımdan) dışlama maliyeti ve rekabetin şiddeti kamu mal1-özel mal ölçeğinde bir malın yerini belirler. Buna göre kullanımdan dışlama maliyetleri azaldıkça ve/veya rekabet arttıkça, yani bir kişinin kullanımı diğerinin kullandığ miktarı azalttıkça malın kamu malı nitelikleri 
azalır ve yarı kamu mallarından özel mallara dönüşümü sağlanır. Bu dönüşüm, ekosistem hizmetleri için ödeme programlarının temelinde yatan düşüncelerden biridir ve yeni bir fikir değildir. Mantau'ya (1996) göre, kamu malları tüketimden dışlama niteliği artırılarak pazarlanabilir ve kullanımda rekabetin artırılması ile de malın değeri artırılır; böylece ekonomik mallara dönüştürülebilir. Merlo ve ekibi (Merlo ve ark., 2000; Merlo ve Briales, 2000) bu düşünceden hareketle, orman kaynaklarının sunduğu kamu mallarının (ekosistem hizmetlerinin) özel mallara dönüşüm yollarını araştırmıştır. Geçmişte Türkiye'yi de kapsayan ve Akdeniz ormanlarının dışsallıklarının ölçülmesini amaçlayan MEDFOREX projesinin (Merlo ve Briales, 2000) ilham kaynağ 1 bu düşüncedir.

Geray, su kaynakları için bu süreci, kıtlık kavramının tutundurulması, faydanın parasal kavramının oluşturulması için ekonomik araçların geliştirilmesi, faydanın parasal değerinin ölçülmesi, pazarın oluşturulması, bu suretle ticarileştirme, özel mallara dönüşüm ve içselleştirme olarak çizmekte ve eleştirmektedir. Dönüşen kamu malı için özel mal yerine "küresel kamu malı ve küresel ortak mal" terimleri kullanılmak suretiyle kaynakların kamusal mal ve hizmet niteliği sürdürülüyor ve onlara yerküre ölçeğinde sahip çıkılıyor görünümü de verilmektedir (Geray, 2005). Ancak böylece bir ülkenin kamu malı dünyaya ait kamu malı noktasına taşınmış olmaktadır.

Orman kaynaklarının Türkiye'de olduğu gibi devlete ait olduğu durumlarda, pazar dışı fayda akımları kasıtlı dışsallıklardır ve vergilerle toplum tarafından finanse edilmektedir. Özellikle kamu malı nitelikleri yüksek olan ekosistem hizmetleri için ticarileştirme yoluyla geleceğe yönelik bu hizmetin kamusal niteliklerinin kaybettirilmesi ve özel mala dönüşümü faydalarının yaygınlığını ve toplumsal refahı azaltacaktır (Kaya, 2006). Bu konuda tartışma, orman kaynaklarının su kalitesini iyileştirme ve biyolojik çeşitliliği koruma gibi işlevleriyle topluma sunduğu ekosistem hizmetlerinde daha fazla öne çıkmaktadır.

Ticarileştirmeyle ilgili başka kaygılar da dile getirilmektedir. Bunlardan biri, ekosistem hizmetleri için ödeme pazarlarında ticari kârlılığı ön planda tutan uygulamaların korumaya yönelik ekonomik savlara baskın olma riskidir (Redford ve Adams, 2009). Bir diğeri ise meta fetişizmidir. Marx'ın yaklaşımı da kullanılarak ekosistem hizmetleri için ödeme programlarında ekosistemlerin karmaşıklığının ve değer elemanlarının sadeleştirilerek alım-satıma konu edilebilecek tek bir hizmete ve tek bir değere indirgenmesi, fiyat yapısı ve mülkiyet hakları tahsisi ile ilgili görünmez kurumsal asimetri meta fetişizmi olarak adlandirılmaktadır (Kosoy ve Corbera, 2010).

Meta fetişizmi, ekosistem hizmetleri için ödeme programlarında tasarımcıların ve aracıların emeğinin doğa ve dolayısıyla orman kaynaklarının ekosistem hizmetleri üretimine katkısının önüne geçmesi ve hizmeti kendilerine mal etmeleridir. Diğer yandan, karbon örneğinde olduğu gibi, karbon fiyatının orman ekosistemi üretim süreçleri, karbon tutma arz1 ve talebinden ziyade emisyon piyasalarında oluşması da bu tartışmada yer bulmaktadır.

\subsection{Mülkiyet haklarının değişimi}

Ekosistem hizmetleri için ödeme programlarının etkin şekilde tasarımı ve uygulaması için mülkiyet haklarının belirlenmesi gerekir. Bununla birlikte çoğu ekosistem hizmeti kamu malı nitelikleri taşıdığından, ya mevcut özel mülkiyet hakları kullanılır ya mülkiyet hakları değiştirilir ya da özelleştirmeksizin ortak mülkiyete dayalı varlık tröstü gibi mülkiyet hakları oluşturulabilir (Farley ve Costanza, 2010). Geray'ın (2005) endişe ettiği mülkiyet hakları değişimi böylece gerçekleşir. Bunun için, kamu mülkiyetinin özelleştirilmesi gerekmeden, rekabet ve özellikle kullanımdan dışlama seviyeleri artırılarak kamu malı niteliklerinin yarı kamu, yarı özel veya özel mallara dönüştürülmesi yeterlidir.

Örneğin, bir ekosistem hizmetleri için ödeme programı dâhilinde orman yönetimi ile yakındaki içme suyu tesisi arasında sürdürülebilir su kalitesi sağlamak üzere yönetim tedbirleri alma konusunda sözleşme düzenlendiğinde, örtük olarak irtifak hakk1 tesis edilmektedir. Sözleşme süresince özel veya toplumsal faydası daha yüksek olabilecek seçenekler ortaya çıksa dahi, irtifak hakkı sahibinin hakları esas alınacaktır.

Mülkiyet hakları değişiminin yaratabileceği sorunlara somut bir örnek Kosta Rika'dan verilebilir. Kosta Rika'da Ulusal Biyolojik Çeşitlilik Enstitüsü (INBio) ile Amerikan ilaç devi Merck arasında 1991 yılında imzalanan sözleşme ile ormanlarda araştırma izinleri tesis edilmiştir (Kaya, 2006). Sözleşme öncesi bu ormanlar küresel düzeyde gelecek değeri taşırken sonrasında sadece bir şirketin kullanımına tahsis edilmiştir. Yeni bir ilaç ham maddesi keşfedildiğinde, sentetiği de üretildiğinde bitki yerine ilacın kullanım değeri oluşacaktır. Bu tür sözleşmeler, kamu kaynaklarının etkin olmayan tahsislerine ve ilaç sektöründe tekel oluşmasına yol açabilir.

\subsection{Fayda ölçümü sorunu}

Ekosistem hizmetleri için ödeme programlarının tasarım ve uygulanmasında karşılaşılan en önemli 
sorunlardan biri ekosistem hizmetlerinin faydas1nın ölçülmesidir. Sorunun hem fiziksel hem de parasal boyutu vardır. Sağlıklı bir ekosistem hizmetleri için ödeme programında ekosistem hizmetinin üretim miktarı ve/veya kalitesini ölçmek, etkileyen değişkenleri ve etki büyüklüklerini belirlemek gerekmektedir. Çoğu ekosistem hizmeti için bu ilişkiler belirsizdir. Örneğin, her orman ekosistemi için su kalitesini etkileyen meşcere parametrelerini ölçmek kolay değildir ve ölçme çabaları işlem maliyetlerinin ekosistem hizmetleri için ödeme programının faydasını aşmasına yol açabilir.

Fayda ölçümünün diğer boyutu ise parasaldır; diğer bir deyişle, sağlanan hizmet karşılığı yapılacak ödemenin büyüklügüünün belirlenmesidir. Faydalanan öder ilkesi gereği, ekosistem hizmetleri için ödeme programı ile sağlanan ekosistem hizmetinin ekonomik değerinin belirlenmesi gerekmektedir. $\mathrm{Bu}$ noktada ekosistem hizmetlerinin ekonomik değerinin belirlenmesine yönelik yöntembilimin kullanılması gerekmektedir. Günümüzde orman kaynaklarının sağladığı ekosistem hizmetlerinin ekonomik değerinin belirlenmesi için yöntembilim oldukça gelişmiştir. Açıklanan tercihlere dayalı seyahat maliyeti ve hedonik fiyatlandırma yöntemleri ile aktif kullanım değerleri; belirlenen tercihlere dayalı koşullu değer belirleme ve seçim deneyleri yöntemleri ile hem aktif hem de pasif kullanım değerleri tahmin edilebilmektedir.

Bununla birlikte, ekosistem hizmetlerinin ekonomik değerinin belirlenmesine yönelik çalışmalar ucuz ve pratik değildir. Değer belirleme yöntembiliminin kısıtlamaları da söz konusudur. Özellikle küresel düzeyde pasif kullanım değerlerinin tahmini güçtür. Bu sorunu, değer tahminlerini zaman ve mekânsal olarak taşıyarak çözmek amacıyla fayda transferi yöntemi geliştirilmiş, hatta değer verisi tabanları oluşturulmuştur. Ancak sınırlı sayıda ülkede ve sınırlı sayıda hizmet için fayda transferi yöntemini etkin kullanabilecek sayı ve güvenilirlikte değer tahmini mevcuttur (Kaya, 2002). Bu kısıtlamalar, bir ekosistem hizmeti için üretilen değer tahminini basit şekilde başka bir ekosistem için kullanmaya yönlendirebilmektedir. $\mathrm{Bu} \mathrm{kez}$ ekosistem hizmetleri için ödeme programlarının güvenilirliği sorgulanabilir. Ayrıca değer belirleme araştırmaları, gelecek kuşakların tercihlerini yansıtmamaktadır ve kuşaklar arası adaletsizliklere yol açabilir yahut var olan adaletsizlikleri düzeltemeyebilir. Orman ekosistemlerinde ilişkilerin karmaşıklığı ve bilgi eksikliği de güvenilir değer tahminlerini üretmeyi güçleştirmektedir.

\subsection{Doğal ekosistemlere pazar etkisi}

Ekosistem hizmetleri için ödeme programlarıyla tasarlanan pazarların ekosistem hizmetleri tan1mının insan merkezli olması, ekosistem hizmetleri arasında biyolojik çeşitliliğin zayıf halka olması ve yapay ekosistemlere teşvik gibi orman ekosistemlerinin doğallığına tehdit oluşturan riskleri söz konusudur (Redford ve Adams, 2009). Bu riskler şu şekilde açıklanabilir:

- Ekosistem hizmetleri, tanımı gereği insanlara fayda sağlayan hizmetleri esas almaktadır. Buna karşın ekosistemlerin kuraklık, yangınlar ve seller gibi insanlara zarar verebilen, ancak bileşenlerinin yaşam döngüsü için önemli olan süreçleri mevcuttur. Ekosistem hizmetleri için ödeme programlarına dâhil olan ekosistem hizmetlerinin sürekliliği için bu süreçlerin engellenmesi, ekosistemlerin uzun vadede ayakta kalması ve diğer ekosistem hizmetleri için risk oluşturabilir.

- Ekosistem hizmetleri için ödeme programları ile karbon tutma hizmetini en üst düzeye çıkarmak ve bu şekilde geliri maksimum k1lmak için doğal türler yabancı türlerle değiştirilebilir. Su kalitesini iyileştirmek için yapraklı türlerle değişim sık yapılan bir uygulamadır. Ekosistem hizmetleri için ödeme programlarında tür tercihi olarak egzotik türlerin kullanılması programın öncelediği ekosistem hizmetini iyileştirebilir ve geliri art1rabilir; ancak bu durumlarda ekolojik kırılganlık artabilir ve biyolojik çeşitliliği barındırma hizmeti olumsuz etkilenebilir. Bir araştırmaya göre (Hua ve ark., 2016), Çin'de gerçekleştirilen Yeşil Buğday Programında monokültür ve yabancı türlerin kullanımıyla bitki ve hayvan tür çeşitliliğine çok fazla zarar verilmiştir.

- Yapay ağaçlar gibi teknolojik yeniliklerle karbon tutma hizmeti maliyet etkin olarak ikame edilebilir ve ekosistem hizmetleri için ödeme programlarında arazi kullanımı tercihleri doğal ekosistemler aleyhine değişebilir.

\subsection{Kırsal kalkınmaya katkı}

Ekosistem hizmetleri için ödeme programlarının kavramsal temelinin gündeme geldiği yıllarda Rio Konferansı ile popüler olan entegre koruma ve kalkınma projelerine ve sürdürülebilir orman kaynakları yönetimi yaklaşımına göre daha sağlam olduğu ve daha maliyet etkin çıktılar üreteceği iddia edilmiştir (Wunder, 2005). Burada hareket noktas1, ekosistem hizmetleri finanse edilirken bir yandan da kırsal topluma gelir transferi yoluyla orman ekosistemlerinin korunmasının sağlanması ve kırsal kalkınmaya destek olunmasıdır.

Buna karşın bir çalışmada (Muradian ve ark., 2013), her iki yaklaşımın da zayıf varsayımlarla ve kanıtlarla hareket ettiği, günümüzde ekosistem 
hizmetleri için ödeme programlarında geçmişte söz konusu entegre projelerde karşılaşılan sorunların benzerleriyle karşılaşıldığ 1 ve ekosistem hizmetleri için ödeme programlarının kazan-kazan çözümü olamayacağı vurgulanmıştır.

Ekosistem hizmetleri için ödeme programları ile kırsal kalkınma arasında iki ana sorundan söz edilebilir. Bunlardan biri, en fakirlerin arazi sahibi olma olasılığının düşüklüğü veya arazi sahibi olsalar dahi geçim sorunları nedeniyle ekosistem hizmetleri için ödeme programına katılmalarının alternatif maliyetinin nispeten yüksek olmasıdır. Örneğin, Kosta Rika'da orman korumaya yönelik ekosistem hizmetleri için ödeme programında hizmet sağlayıcıların çoğu nispeten daha varlıklı arazi sahipleriyken (Kosoy ve ark., 2007) Latin Amerika'da incelenen sekiz ekosistem hizmetleri için ödeme programında (GriegGran ve ark., 2005) yine fakir arazi kiracıları dışlanmıştır. Bu soruna karşı köy topluluklarının daha avantajlı olduğu düşünülebilir.

Bir başka sorun, kırsal toplumun ana gelir kaynağı odun ham maddesi üretim işleri veya temel ihtiyaçları odun ham maddesi üretimine bağlı ise ortaya çıkmaktadır. Söz gelimi, biyolojik çeşitliliği korumak amacıyla bir ekosistem hizmetleri için ödeme programı ile odun ham maddesi üretimi engellendiğinde veya azaltıldığında arazi sahiplerine yapılan ödemeler kırsal fakirliği azaltmaya hizmet etmeyebilir.

Bir araştırmaya (Gong ve ark., 2010) göre, Çin'de ekosistem hizmetleri için ödeme programlarında fayda dağılımı kereste şirketleri ile köy topluluklar1 arasında çatışma yaratmıştır. Kamboçya'da ekosistem hizmetleri için ödeme programları üzerine bir çalışma (Clements ve ark., 2010), ekosistemleri koruma ve fakirliği azaltma amaçları arasında uzun dönemde ekosistem hizmetleri için ödeme programlarının performansını da etkileyebilecek bir dengenin olduğunu göstermiştir.

$\mathrm{Bu}$ araştırmalardan hareketle ekosistem hizmetleri için ödeme programlarının fakirliği azaltmaya yönelik etkileri hakkında kanıtların çelişkili olduğu bildirilmektedir (Muradian ve ark., 2010; Muradian ve ark., 2013).

\subsection{Finansal aracılar ve paranın dolaşımına katkı}

Aracıların ekosistem hizmetleri için ödeme programlarının tasarımından uygulanmasına, izlenmesinden denetimine kadar genelde baskın role sahip olduğu görülmektedir (Kosoy ve Corbera, 2010; Vatn, 2010). Mevcut programlar ve aracı kurumların faaliyetleri incelendiğinde, ekosistem hizmetleri için ödeme programı talebinin yaratılması da bu rolün önemli bir parçasıdır. Bu noktada aracıların ekosistem hizmetleri için ödeme programlarında sürdürülebilir orman kaynakları yönetimine etkisi iki şekilde olabilmektedir. Birincisi, bilgi birikiminin yetersiz olduğu gelişmekte olan ülkelerde teknik bilgi desteği; ikincisi ise yeni pazarlarla yaratılan finansal akışı yönetmektir.

Literatür incelendiğinde, ilk boyutta ön plana ç1kan Forest Trends ve Katoomba Group gibi "kâr amaçlı olmayan" organizasyonlar, ekosistem hizmetleri için ödeme programlarının gelişmesi için kurulmuşlardır ve aracı gibi çalışmaktadırlar. Çevre ve ormancılıkla ilgili FAO, ITTO, WWF ve diğer uluslararası organizasyonların da sürece katk1sı bilinmektedir.

Asıl ilgi çekici olan ikinci boyuttur. Küresel düzeyde ekosistem faydalarının toplam yıllık değerinin 33 trilyon \$ olduğu tahmin edilmiştir (Costanza ve ark., 1997). 1995 yılı değerleriyle küresel GSYH'nin yaklaşık iki katı olan bu değer küresel finans sistemi aktörlerinin iştahını açmaktadır. Ekosistem hizmetlerinin değerinin dünyada paranın dolaşımına katkı sağlaması için yeni pazarların kurulması ve finansal olarak desteklenmesi gerekmiştir. Ekosistem hizmetleri için ödemeler, bu noktada ekosistem hizmetlerinin ticarileştirilerek yeni pazarlar tesis edilmesi için program tasarımlarıdır. Ayrıca doğal etkilere açık programların sigortalanması da gerekmektedir. O nedenle ekosistem hizmetleri için ödeme programlarının geliştirilmesi amacıyla gerekli kapasiteyi desteklemek ve iyileştirmek için kurulan ağların ve STK'ların kurucuları ve destekçileri arasında çok uluslu şirketlerin, finans kuruluşlar1 ile organik bağı olan vakıfların olması bu açıdan şaşırtıcı değildir. Muradian ve ark.'ına (2010) göre, finansal aracıların rolünü yansıtmak üzere alıcılar ve satıcılar arasındaki kaynak transferi ve aracıların payı konusunda yeterli araştırma bulunmamaktadir.

\subsection{Koruma güdülerinde değişim}

Ekosistem hizmetleri arasında doğrudan kullanım değerine sahip olanlar için faydalanan kitleyi belirlemek, dolaylı kullanım değerleri bulunduranlara göre daha kolaydır. En zoru ise pasif kullanım değerleri taşıyanlara erişmektir. Ekosistem hizmetleri için ödeme programlarında STK'ların rolü bu noktada devreye girmektedir. STK'lar, pasif kullanım değeri taşıyanların bağışlarıyla, hizmet alıcısı aktörler olarak ekosistem hizmetleri için ödeme programlarında yer alırlar.

Pasif kullanım değerlerini ekosistem hizmetleri için ödeme programlarıyla yakalamak ve parasal 
büyüklüklere dönüştürebilmek için toplumun orman ekosistemlerini korumaya yönelik tutumlarının ve arkasındaki koruma güdülerinin yüksek olması gerekir. Buna karşın, ekosistem hizmetleri için ödemelerin tanımındaki koşullu parasal ödeme, dişlama etkisine yol açabilir ve para ödenmediğinde korumaya desteği azaltabilir. Bu soruna yönelik bazı kanıtlar mevcuttur (Muradian ve ark., 2010; Farley ve Costanza, 2010).

\subsection{Sağlam düşünsel altyapı}

Ok (2012), ekosistem hizmetleri için ödemeler konusunun üç boyutu olduğunu bildirmektedir. Bunlardan biri, ekosistem hizmetlerinin sürekliliğini sağlamak için hizmet üretenlerin finansmanıdır. İkincisi, daralan pazarlara yeni soluklar açtıracak yeni piyasalar oluşturmadır. Bu iki boyut yukarıda ele alınmıştır. Ok, ekosistem hizmetleri için ödemeler konusunun üçüncü boyutu olarak uluslararas1 rekabette yeni entelektüel mücadele alanı olmasina işaret etmektedir.

Ekosistem hizmetleri için ödemelerin dayanaklarının adalet ve bölüşüm gibi refah iktisadının temel alanlarıyla, farklı çevresel endişe motifleriyle ve çevre etiğiyle ilgisi, düşünce sistemlerine ve savunucularına yeni tartışma alanı yaratmaktadır. Kapitalist-sosyalist, insan merkezli-ekomerkezli, egomerkezli-sosyal özgecil-biyomerkezli çevresel değer yönlendirmesi kutuplarında ve aralıklarında yer alanların savunabileceği yahut reddedebileceği kanıtların türetilmesine açık olması konuya düşünsel boyut katmaktadır. Böylece her iktisadi düşünce sisteminin taraftarlarına kendilerini ifade etmeleri için firsat alanı sağlamaktadır. Daha ötesinde ister kapitalist ister sosyalist yahut katı çevreci veya çevre karşıtı olsun, herkesin destekleyebileceği veya karşı çıkabileceği ekosistem hizmetleri için ödeme programı örneklerinin bulunması uzlaşma ya da çatışma ortamı yaratırken çıkar gruplarına düşünsel altyapısı daha sağlam bir alanda hareket esnekliği sağlamaktadır.

\subsection{Ekosistem hizmetleri için ödeme program- larının etkinliği ve Türkiye'deki olanaklar}

Her yıl dünyada, ekosistem hizmetleri için ödemelerin kavramsal temelini, tasarım ve uygulama süreçlerini açıklayan ortalama 1765 makale yayınlanmasına rağmen (Börner ve ark., 2017) ekosistem hizmetleri için ödeme programı uygulamalarının ormanların korunmasına yönelik etkinliğini gösteren çok az kanıt bulunmaktadır (Salzman ve ark., 2018; Muradian ve ark., 2013; Börner ve ark., 2017; Tacconi, 2012; Ferraro, 2017). Belki de bu yüzden ekosistem hizmetleri için ödemelerin kamu malları için henüz olgunlaşmamış pazarlar yaratan teşvik mekanizmaları olduğu ifade edilmektedir (Arrigada ve Perrings, 2009).

Ekosistem hizmetleri için ödemelerin doğuşundaki temel yaklaşım izlenerek dünyada ekosistem hizmetleri için ödeme programlarının büyük çoğunluğunun ulusal veya yerel hükümetler dişındaki özel veya tüzel kişilere ait orman veya diğer arazi kullanımları için tasarlandığı görülmektedir. Ormanlarının \%99'u devlet mülkiyetinde olan Türkiye'de sürdürülebilir orman kaynakları yönetiminden sorumlu kamu kurumlarının gelirlerinin özel, genel ve döner sermaye bütçeleri altında satışlar, kullanım bedeli gelirleri, tahsisler, hükümet yatırım ve destekleri, hazine katkısı ve şartlı bağışlardan oluştuğu bilinmektedir. Bu finans kaynaklarının iyileştirilmesi için birçok öneri mevcuttur (Ok ve ark., 2013). Bu ormanların ürettiği pazarı olmayan mal niteliğindeki ekosistem hizmetlerinin finansmanı devlet vergi gelirlerinden oluşan hazine katkısı ile sağlanmaktadır. Hazine katkısı içindeki ormancılık sektörü kaynaklı olmayan vergi geliri paylarının iyileştirilmesine ihtiyaç olsa da bu ayrı bir konudur.

Ticari kaynak suyu işletmelerinden izin bedelleri ve rekreasyon hizmetleri için alınan kullanım bedelleri geniş anlamda ekosistem hizmetleri için ödemeler olarak görülebilir. Ancak devletin, ormanlarından bu faydaları topluma sağlama görevi vardır ve karşılığını vergilerle almaktadır. Bu tür bedeller daha çok faydalanmanın düzenlenmesi için alınmaktadır. Pasif kullanım veya kullanımdışı değerler için yurt içinden şartlı bağışlar ve STK'ların ortak projeleri, yurt dışından ise dış kaynaklı projeler ve resmi kalkınma yardımları ile finansal destekler bulunmaktadır.

Devlet ormanlarının yaydığı özellikle sınırı aşan faydalar için pazar ortamı dışında finansman olanaklarını geliştirmek amacıyla sürdürülebilir orman kaynakları yönetiminin finansmanına yönelik olarak ülkelerin haklarına ve sorumluluklarına dayalı bir öneri (Ok ve ark., 2014) mevcuttur. Bu öneriye dayanarak ülkelerin sürdürülebilir orman yönetimi doğrultusunda yerine getirdikleri sorumluluklarına göre haklarını elde etmek üzere ekosistem hizmetleri için ödeme programlarını düzenleme olanağı vardır. Bu şekilde ormanların sağladığı sınırı aşan ekosistem hizmeti faydaları, özellikle pasif kullanım değerlerinin üretimi finanse edilebilir.

Ekosistem hizmetleri için ödeme programlar1, Türkiye'de çok zayıf olan özel ormancılığ1 geliştirmek ve doğal ekosistemlere zarar verebilen arazi ve su kaynakları kullanımlarını engellemek için olanak sağlamaktadır. Birçok ülkede marjinal tarım arazilerinin ağaçlandırmalar ve ormanlık alanlara dönüştürülmesi, tarım arazilerinde 
tarımsal-ormancılık sistemlerinin kullanılması ve tarım arazilerinde çevre ekosistemlere zarar veren kimyasalların kullanımının düzenlenmesi amacıyla alıcının kamu veya özel sektör (gönüllü karbon piyasaları gibi) olduğu ekosistem hizmetleri için ödeme programları uygulanabilmektedir.

Devlet ormanları dışındaki ormanlarda karbon tutma, su kalitesini iyileştirme, hatta daha geniş anlamda ele alınarak rekreasyon hizmetleri, estetik hizmetler ekosistem hizmetleri için ödeme programlarına konu olabilir. Örneğin bir araştırmada (Kaya ve Özyürek, 2015), Ankara şehir merkezinde yer alan ODTÜ Ormanının manzara değeri, çevredeki konut fiyatlarına etkisi kullanılarak hesaplanmış; bu değerden yola çıkarak Büyükşehir Belediyesinin ODTÜ Ormanının estetik faydaları sayesinde elde ettiği yıllık ek vergi geliri hesaplanmıştır. Bu vergi gelirinin ODTÜ Ormanının yönetiminde kullanılması amacıyla bir ekosistem hizmetleri için ödeme programı tasarlama olanağ1 görülmektedir. Üstelik değer ölçme sorunu da araştırmayla giderilmiştir.

\section{Tartışma ve Sonuçlar}

Araştırmada son on yılda gelişmiş veya gelişmekte olan birçok ülkede yaygınlaşan ve ekosistem hizmetlerini finanse etmede yenilikçi bir araç olarak gösterilen ekosistem hizmetleri için ödeme programları çok boyutlu olarak irdelenmiş, orman ekosistem hizmetlerinin sürdürülebilir yönetimi için firsat ve tehdit alanları ortaya konmuştur. Öncelikle Coase'nin sözleşmelerinden Pigou araçlarına, Wunder'in tanımından Muradian ve arkadaşlarının tanımına doğru ekosistem hizmetleri için ödemelerin kapsamı, çeşitliliği ve etkinliğinin arttığ görülmektedir. Daha da ötesinde ekosistem hizmetleri için ödemelerin, hiçbir kısıtlama konmaksızın ekosistem hizmetlerinde faydalanma karşılı̆̆ yapılan tüm ödemeleri kapsaması gerektiği açıktır.

Günümüzde sorun ekosistem hizmetlerinin finansmanı olduğuna göre, ödeme araçlarını çeşitlendirmek ve dar bir alanla kısitlamamak gerekir. Wunder'in tanımı çerçevesinde dünyada yürütülen programlar ise ekosistem hizmetleri için ödemeler kapsamında ekosistem hizmetleri için gönüllü sözleşmeler olarak adlandırılmalıdır. $\mathrm{Bu}$ bilgiler 1şı̆̆ında ekosistem hizmetleri için ödemeler, pazar mekanizması yeterli teşvik sağlamadığında, örneğin orman kaynaklarının ürettiği pazarı olmayan ürün ve hizmetlerden orman sahibi gelir elde etmediğinde, bu ürün ve hizmetleri devamlı sağlamaları karşılığında orman sahiplerine fayda elde edenler tarafından doğrudan veya dolaylı, aracılarla veya aracısız yapılan ödemeler olarak tanımlanmalıdır. $\mathrm{Bu}$ şekilde taraflar arasında fayda-değer transferi gerçekleşmektedir.

Uygulamada ekosistem hizmetleri için ödeme programlarının etkinliğine yönelik delillerin az olmasına ve şüphelerin varlığına rağmen, kamu ve/ veya özel finans kaynaklarının yetersiz olduğu ülkelerde ekosistemlerin sürdürülebilir yönetimi için önemli fırsatlar sağladığı açıktır. Ekosistemlerin faydalarının sürekliliğinin yanı sıra, ekosistemlere zarar veren uygulamalar engellenebilmektedir. $\mathrm{Bu}$ bağlamda ekosistem hizmetleri için ödeme programları, Türkiye'de özel ağaçlandırmalar ve ormancılığın teşviki, ormancılık dişında ise sulak alanlar, yaban hayatı ekosistemleri ve gida güvenliğine zarar verebilen tarımsal uygulamaların engellenmesinde etkin araçlar olarak kullanılabilir.

Devlet ormanları dıșındaki ormanların ekosistem hizmetlerinin faydaları için vergi gelirlerinden transferler yapılabilir. Devlet ormanları içinse şart11 bağışlar ekosistem hizmetleri için ödeme programlarına bağlanabilir. Özellikle korunan alanlarda tek bütçe ilkesi istisnaları yaratılmalıdır.

$\mathrm{Bu}$ araştırmada ihmal edilen hukuki boyut araşt1r1lmalı, orman ekosistem hizmetlerini tanımlayan ve özel mülkiyetteki araziler ağaçlandırıldığında orman toprağı sayılmasının arazi sahiplerine getireceği kısıtlamaları aşacak yasal düzenlemeler yapılmalıdır.

Makalede ekosistem hizmetleri için ödeme programlarının ticarileştirme, mülkiyet hakları değişimi, değer belirleme sorunu, bazı hizmetlerin finansmanında doğal ekosistemlerin zarar görmesi, ekosentrik güdüleri azaltma, en fakirlerin dışlanması, finansal aracıların çalışma alanı olması, doğal ekosistemlerin değişimi gibi ekosistemler üzerinde tehdit oluşturabilecek riskleri taşıdığ 1 belirlenmiştir. Bu tehditlere karş1 aşağıdaki önlemler alınabilir:

- Mahsuplaşmalar ve mahsuplara dayalı koruma bankacılığı gibi çevre etiğine uygun olmayan ekosistem hizmetleri için ödeme programları kullanılmamalıdır.

- Kamu arazilerinde yürütülecek ekosistem hizmetleri için ödeme programlarında net kamu yararı aranmalı, kamunun mülkiyet hakları zedelenmemelidir.

- Kirsal toplumda arazi sahibi olmayan veya küçük arazi sahibi olan en fakir kesimin yararlanmasi maksadıyla ekosistem hizmetleri için ödeme programlarında ortaklıkların ve istihdam yaratıcı faaliyetlerin tasarlanması gerekir.

- Finansal aracıların rolünü, kamu kuruluşları, çevre koruma STK'ları ve uluslararası kuruluş- 
lar üstlenmelidir.

- Ekosistemlerin sınırları aşan pasif kullanım değerlerini finanse etmek için Birleşmiş Milletler gözetiminde bir fon aracılığıyla ülkelerin hak ve sorumluluklarına dayalı bir mahsuplaşma çerçevesinde ekosistem hizmetleri için ödeme programları yürütülmelidir.

- Doğal ekosistemlerde yürütülen programlarda biyolojik çeşitliliğin önceliği sınanarak ekosistem hizmetleri için ödeme programı tasarlanmalıdir.

- Ekosistem hizmetleri için ödeme programlar1nın sadece bir finansman aracı olduğu unutulmamalı, orman kaynakları yönetimine yönelik politika, plan ve projelerle bütünleşik olarak kullanılmalıdır.

Son söz olarak, tanımı insan merkezli olan ekosistem hizmetleri yaklaşımının, ekosistemin insan dışı ögeleriyle bütünleştirilmesi sağlanmalı ve böylece ekosistemin insan dışı ögelerine yönelik olarak ekosistem hizmetleri için ödeme programları tasarlanmalidir.

\section{Teşekkür}

Bu çalışma; 04-06 Ekim 2018'de Bursa'da düzenlenen 4. Uluslararası Odun Dışı Orman Ürünleri Sempozyumu'nda sözlü olarak sunulmuş ve sadece özeti yayımlanmış olan bildirinin tam metnidir.

\section{Kaynaklar}

Anonim, 2005. Ecosystems and Human Well-Being: Synthesis Report. Island Press, Washington DC

Anonim, 2008. Payments for Ecosystem Services Getting Started: A Primer. UNON Publishing Services Section, Nairobi

Anonim, 2011. Payments for Forest- related Ecosystem Services: What role for a Green Economy? - Background Paper for the UNECE Workshop, July 2011, Geneva, 46p

Anonim, 2012. Study on Forest Financing, Advisory Group on Finance Collaborative Partnership on Forests. http://www.un.org/esa/forests/index.html (Erişim tarihi: 15 June 2012)

Anonim, 2014. The Value of Forests. Payments for Ecosystem Services in a Green Economy. Geneva Timber and Forest Study Paper 34 (ECE/TIM/SP/34), Geneva: United Nations

Anonim, 2018. Ecosystem Services \& Biodiversity. http://www.fao.org/ecosystem-services-biodiversity/en/ (Erişim tarihi: 10.08.2018)

Arriagada, R., Perrings, C., 2009. Making Payments for Ecosystem Services Work. United Nations Environment
Programme, Nairobi, Kenya

Börner, J., Baylis, K., Corbera, E., Ezzine-de-Blas, D., Honey-Roses, J., Persson, U. M., Wunder, S., 2017. The effectiveness of payments for environmental services. World Development 96 (2017): 359-374

Clements, T., John, A., Nielsen, K., Dara, A., Setha, T. T., Milner-Gulland, E. J., 2010. Payments for biodiversity conservation in the context of weak institutions: Comparison of three programs from Cambodia. Ecological Economics 69 (6), 1283-1291

Costanza, R., d'Arge, R., de Groot, R., Farber, S., Grasso, M., Hannon, B., Limburg, K. E., Naeem, S., O’Neill, R. V., Parueloi J., Raskin, R. G., Sutton, P., van den Belt, M., 1997. The value of the world's ecosystem services and natural capital. Nature 387, 253-260

Derissen, S., Latacz - Lohmann, U., 2013. What are PES? A review of definitions and an extension. Ecosystem Services 6: 12-15

Farley, J., Costanza, R., 2010. Payments for system services: from local to global. Ecological Economics 69, 2060-2068

Ferraro, P. J., 2017. Are payments for ecosystem services benefiting the ecosystems and people? In: Kareiva, P., Marvier, M., \& Silliman B. (Eds.), Effective Conservation Science: Data not Dogma, Oxford University Press, pp.159-166

Geray, U., 2005. Ormanlar ve su politikası. Haftanın Yaz1sı, Çekül Vakfi. http://www.cekulvakfi.org.tr, (Erişim tarihi: 15.05.2005)

Gong, Y. Bull, G., Baylis, K., 2010. Participation in the world's first clean development mechanism forest project: the role of property rights, social capital and contractual rules. Ecological Economics 69 (6), 1292-1302

Grieg-Gran, M., Porras, I.,, Wunder, S., 2005. How can market mechanisms for forest environmental services help the poor? Preliminary lessons from Latin America. World Development 33(9): 1511-1527

Hua, F., Wang, X., Zheng, X., Fisher, B., Wang, L., Zhu, J., Tang, Y., Yu, D. W., Wilcove, D. S., 2016. Opportunities for biodiversity gains under the world's largest reforestation program. Nature Communications 7: 12717

Kaya, G., 2002. Pazarı Olmayan Ürünler Çerçevesinde Orman Kaynaklarının Değerinin Belirlenmesi. Doktora Tezi, İstanbul Üniversitesi Fen Bilimleri Enstitüsü, İstanbul

Kaya, G., 2006. Tibbi bitki rezervi olarak orman kaynaklarının gelecek değerinin belirlenmesinde kullanılan P\&P modelinin irdelenmesi. Bartın Orman Fakültesi Dergisi (1): 1-10

Kaya, G., Özyürek, E., 2015. Kent ormanı anlayışıyla ODTÜ Ormanı manzarası için ekonomik değerin tahmin edilmesi. Ormancılık Araştırma Dergisi 2015/1, A, 
Say1:1:2, 15-28

Kosoy, N., Martinez-Tuna, M., Muradian, R., Martinez-Alier, J., 2007. Payments for environmental services in watersheds: insights from a comparative study of three cases in Central America. Ecological Economics $61,446-455$

Kosoy, N., Corbera, E., 2010. Payments for ecosystem services as commodity fetishism. Ecological Economics 69, 1228-1236

Madsen, B., Carroll, N., Kandy, D., Bennett, G., 2011. Update: State of Biodiversity Markets. Washington, DC: Forest Trends. http://www.ecosystemmarketplace.com/ reports/2011_update_sbdm (Erişim tarihi: 10.09.2018)

Mantau, U., 1996. Alternative ways of correcting market failure product structures- a key to marketability. Proceedings of International Symposium on the Non-Market Benefits of Forests, June 24-28, 1996, Edinburgh, UK

Merlo, M., Briales, E. R., 2000. Public goods and externalities linked to Mediterranean forests: economic nature and policy. Land Use Policy (17): 197-208

Merlo, M., Milocco, E., Panting, R., Virgilietti, P., 2000. Transformation of environmental recreational goods and services provided by forestry into recreational environmental products. Forest Policy and Economics (1): 127-138

Muradian, R., Corbera, E., Pascual, U., Kosoy, N., May, P. H., 2010. Reconciling theory and practice: an alternative conceptual framework for understanding payments for environmental services. Ecological Economics 69 (6): $1202-1208$

Muradian, R., Arsel, M., Pellegrini, L., Adaman, F., Aguilar, B., Agarwal, B., Corbera, E., Ezzine de Blas, D., Farley, J., Froger, G., Garcia-Frapolli, E., GómezBaggethun, E., Gowdy, J., Kosoy, N., Le Coq, J.F., Leroy, P., May, P., Méral, P., Mibielli, P., Norgaard, R., Ozkaynak, B., Pascual, U., Pengue, W., Perez, M., Pesche, D., Pirard, R., Ramos-Martin, J., Rival, L., Saenz, F., Hecken, G., Vatn, A., Vira, B., Urama, K., 2013. Payments for ecosystem services and the fatal attraction of win-win solutions. Conservation Letters 6 (4), 274-279

Myers, N., 1996. Environmental services of biodiversity.
Proceedings of the National Academy of Science of the United States of America, 93, 2764-2769.

Ok, K., 2012. PES Doğrusu, fuarhabercisi.net, 20.05.2012 tarihli köşe yazıs1

Ok, K., Kaya, G., Güneș, Y., Koçer, S., Kayacan, B., Eker, Ö., Çağdaş, B., Koșdemir, Z., Yılmaz, E., Bakır, B., Turhan, Ü., 2013. Birleşmiş Milletler Orman Forumu 10. Oturumu İçin Ormancılığın Finansmanı Raporu, Teknik Rapor, 42s

Ok, K., Izlar, B., Siry, J., 2014. Sustainable Finance for Sustainable Forestry: Is Cooperation Possible among Nations? Formath, Vol. 14

Redford, K., Adams, W., 2009. Payment for ecosystem services and the challenge of saving nature. Conservation Biology 23(4): 785-787

Salzman, J., Bennett, G., Carroll, N., Goldstein, A., Jenkins, M., 2018. The global status and trends of Payments for Ecosystem Services. Nature Sustainability Vol. 1, pp. 136-144

Scherr, S. J., Bennett, M. T., Loughney, M., Canby, K., 2006. Developing future ecosystem service payments in China: lessons learned from international experience. Beijing: CCIED, Forest Trends

Stanton, T., Echavarria, T. M., Hamilton, K., Ott, C., 2010. State of Watershed Payments: An Emerging Marketplace. Ecosystem Marketplace, http://www.foresttrends.org/documents/files/doc2438.pdf (Erişim tarihi: 13.09.2018)

Tacconi, L., 2012. Redefining payments for environmental services. Ecological Economics 73, 29-36

Vatn, A., 2010. An institutional analysis of payments for environmental services. Ecological Economics 69 (6), $1245-1252$

Wunder, S., 2005. Payments for Environmental Services: Some nuts and bolts. Bogor: CIFOR Occasional Paper, No. 42

Wunder, S., 2015. Revisiting the concept of payments for environmental services. Ecological Economics 117: $34-243$ 